Cyberbullying: a brief research study emphasizing junior high students' perceptions regarding the cyberbullying phenomenon

Chiș Olga, Adina V. Lung 


\title{
Cyberbullying: a brief research study emphasizing junior high students' perceptions regarding the cyberbullying phenomenon
}

\author{
Chiș Olga ${ }^{a *}$, Adina V. Lung ${ }^{b}$ \\ ${ }^{a}$ Faculty of Psychology and Educational Sciences, Babeș-Bolyai University, 7 Sindicatelor Street, Cluj-Napoca, 400029, Romania \\ ${ }^{b}$ Theoretical High School Nicolae Bălcescu, 6 Constanţa Street, Cluj-Napoca, 400158, Romania \\ *Corresponding author: olga_marcus@yahoo.com
}

\section{Abstract}

\section{Keywords:}

cyberbullying; awareness level; strategies; coping; prevention
The present study is a result of a psycho-pedagogical experiment with junior high students' perceptions regarding the cyberbullying phenomenon. The experimental program, based on a needs analysis and carried out by the survey method (questionnaire developed by the authors), was used to increase and measure students' awareness of the cyberbullying phenomenon. While some students consider cyberbullying a major issue, others do not acknowledge its presence. The psycho-pedagogical experiment focused on a set of strategies for preventing, combatting and approaching (coping with) the elements and specific situations of cyberbullying, communication with an adult, interpersonal communication at group level, role-playing, games, etc. The activities in the experimental program were meant to prevent the phenomenon of cyberbullying and placed a special emphasis on the key role of parents and educators in assisting students.

\section{Zusammenfasung}

Schlüsselworte:

Cybermobbing;

Bekanntheitsgrad;

Strategien;

Bewältigung;

Prävention
Vorliegende Studie ist das Resultat eines psycho-pädagogischen Experimentes mit Kindern in den Klassen 9 zu der Wahrnehmung des Phänomens cyberbullying. Das experimentelle Programm, das nach einer Bedarfsanalyse durchgeführt wurde, die mit der Erhebungsmethode auf der Grundlage eines von den Autoren entwickelten Fragebogens durchgeführt wurde, wurde verwendet, um das Bewusstsein der Schüler für das oben genannte Phänomen zu erhöhen und zu messen. Während einige Studenten Cybermobbing als Hauptproblem betrachten, erkennen andere seine Anwesenheit nicht an. Das psychopädagogische Experiment stützte sich auf eine Reihe von Strategien zur Verhinderung, Bekämpfung und Annäherung (Bewältigung) der Elemente und spezifischen Situationen von Cybermobbing, Kommunikation mit Erwachsenen, zwischenmenschlicher Kommunikation auf Gruppenebene, Rollenspielen usw. Die Aktivitäten im experimentellen Programm sollen das Phänomen des Cybermobbings verhindern und einen besonderen Schwerpunkt auf die Schlüsselrolle von Eltern und Erziehern bei der Unterstützung von Schülern legen.

\section{Introduction}

The physical, verbal or emotional aggressiveness in the educational environment has always been present overtly or covertly, but because of the media, the various social networks, one can say that it has become a phenomenon called bullying that may occur at different ages and have different forms, direct, online, electronic etc (Chiș \& Grec, 2019).

As children began spending more and more time interacting with each other online, a new phenomenon known as cyberbullying has emerged and has become increasingly prevalent, particularly among teenagers. Thus, it has become an issue that has drawn the attention of both parents and educators.

In Romania, research on education and the online environment has been realized so far in relation to generation Z learning skills (Dulamă et al., 2019), to web- based research and e-learning (Ilovan et al., 2015; Ilovan, 2019; Ilovan et al., 2019), to using online apps and web sources in learning through discovery (Rus et al., 2019), and especially to e-learning using Facebook (Dulamă et al., 2015; Dulamă, Ilovan \& Buș, 2016; Dulamă, Vana \&Ilovan, 2016). Most of these studies focus on improving e-learning at the university level.

In this context, our paper fills a gap in research on education and the online environment, focusing on the spreading phenomenon of bullying, with a high impact in school and outside it.

\section{Problem statement}

A common definition of cyberbullying is that provided by Hinduja and Patchin (2015) in their book Bullying Beyond the Schoolyard: Preventing and Responding to 
Cyberbullying, where the authors refer to this phenomenon as a "willful and repeated harm inflicted through the use of computers, cell phones, and other electronic device" (Hinduja \& Patchin, 2015, p 5).

One of the main goals of the study was to test students' awareness levels regarding the cyberbullying phenomenon. When asked to provide examples of cyberbullying, $35 \%$ of the students in the focus group mentioned mean comments as a means of harassment online, $33 \%$ made reference to offensive pictures being posted online, $27 \%$ considered spreading online rumors a form of harassment, and the other $4 \%$ indicated other reasons, but not specific ones. Furthermore, $42 \%$ of the students who completed the survey believe that cyberbullies harass others in order to make themselves feel better, $32 \%$ of those questioned consider that cyberbullies have issues at home, are hurt and thus attempt to hurt others as well; $11 \%$ of the students believe that cyberbullies are jealous of others, and another $11 \%$ indicated other non-specific reasons, while only $5 \%$ of the students believe that cyberbullies harass others as a joke.

When asked why they do not consider cyberbullying a good idea, $53 \%$ of the students in the focus group believe that cyberbullying hurts others, $29 \%$ indicated that cyberbullying can lead to suicide, and only $18 \%$ believe cyberbullying is a bad idea simply because others can see the posts.

\section{Research Questions}

The perceptions of students in the focus group regarding the phenomenon of bullying and cyberbullying were identified in the school year 2018-2019 using a questionnaire of authors' own conception which included 11 questions that the students were asked to answer during school hours. All answers were anonymous and have provided valuable insight into the various ways students perceive cyberbullying, the means they use to cope with it, as well as the strategies they implement to avoid its unpleasant outcomes.

During the pedagogic experiment the following research questions have been explored:

1. How can we identify bullying situations at school and online?

2. What effect does the experimental program have on preventing the phenomenon of cyberbullying?

\section{Purpose of the Study}

The main aim of the study was to emphasize students' various levels of awareness regarding the cyberbullying phenomenon and to translate their responses into a plan meant to raise awareness on the issue, help students cope with the phenomenon, and aid them in preventing its occurrence.
In order to raise students' awareness towards cyberbullying, after interpreting the results, we devised and implemented an intervention program tailored for the focus group.

Various strategies have been proposed such as prevention strategies, prevention of and coping with situations specific to cyberbullying, communication with an adult, interpersonal communication within the group and role play.

\section{Research Methods}

In this research the following methods have been used: the pedagogical experiment, the focus group and direct observation of students, analysis of documents.

The research took place in the 2018-2019 school year and had as a focus group 19 freshman students (grade 9) who were attending Logos Christian Academy in Illinois, USA.

The needs analysis has been devised based on observations and class discussions regarding bullying as well as various observations made throughout school years. These observations indicated that some students consider cyberbullying as non-existent or are not fully aware of its seriousness and implications.

In the pre-experimental stage, we administered an investigation variant, namely the indirect written investigation with the purpose of selecting the content in order to apply the psycho pedagogical experiment. The interpretation of the answers received from the first questionnaire was the starting point for the discussions and activities as part of the initiated experimental program. Thus, as part of the research, an initial questionnaire for students was used.

The initial questionnaire was compiled after consulting various materials that can be found on www.kidshealth.org, www.nsteens.org and www.cyberbullying.org and after reading Jane Hunt's book Bullying: Bully no More.

\section{The intervention program}

The pillars of the intervention program were chosen based on the students' answers received in the initial questionnaire: awareness of the phenomenon of online harassment and its implications, online harassment, suicidal tendencies, the circular nature of harassment, motives, coping strategies, the effects of long-term harassment.

The proposed study focused on the application of a training program conducted over eight weeks. The program included activities to identify, prevent and combat cyberbullying. We selected for presentation and discussed with the students the following topics and ways of intervention: increasing self-esteem, identifying the roles of 
the aggressor, victim, witness, as well as concrete ways to prevent and respond in cyberbullying situations. We also mentioned some ways to achieve the above mentioned aspects: role play, debate sessions, watching videos, etc.

The aim was to emphasize the elements which indicated a sufficient awareness of cyberbullying and its implications (such as suffering inflicted by cyberbullying, to the point of prompting suicide) but also an insufficient awareness of some of the implications of cyberbullying (the circular nature of cyberbullying, reasons for cyberbullying, strategies for copying with the cyberbully, effects and implications of cyberbullying).

\section{Findings}

Our findings indicate that bullying and cyberbullying situations can be identified by observing students' behaviour and language both at school and in the online environment.

The experimental program meant to prevent cyberbullying had several results:it approached a phenomenon known by most students, it led to open class discussions regarding the phenomenon, it helped raise students' awareness of the phenomenon, it posed several challenging questions regarding how students can cope with and prevent the phenomenon, and it helped create a safe environment where students felt more comfortable to share their thoughts and ask for help from adults. A vital element in the prevention of cyberbullying is awareness of the phenomenon and the appropriate training of adults (both teachers and parents) so as to enable them to identify the phenomenon, its victims, and properly assist students who are cyberbullied.

The focus group pertaining to this study is a clear example that open, frank discussions regarding cyberbullying and practical advice offered to children can be of help to them in knowing how to deal with existing or potential cyberbullying instances. After the focus group completed the surveys, a prevention and coping program was tailored based on their answers and was carried out for several weeks during school hours.

At the end of the survey, students were asked, among other questions, how they would respond if they were cyberbullied online; $36 \%$ (compared to only $28 \%$ in the initial survey) said that they would ignore the aggressor's comments, and $26 \%$ (compared to only $11 \%$ in the initial survey) affirmed that they would discuss the matter with an adult. However, the percentage remained almost identical regarding the possibility of confronting the aggressor $(22 \%$ in the first survey compared to $21 \%$ in the second survey).

\section{Conclusion}

Although online disagreements are not always the cause for cyberbullying, the phenomenon seems to be increasingly prevalent. The intervention to prevent the bullying phenomenon will enable the protection of children against all types of aggression, violence, ensuring the school and community safety for our children (Chis \& Grec, 2019).

The interpretation of the results points to the fact that a significant number of the participants in this study (over $50 \%$ of them) considered useful and helpful the class activities throughout the program and the mottos introduced during the second week of the program

Both parents and educators play a key role in educating children and teens about the prevalence and risks of cyberbullying. The study also concludes that an 8-week intervention program is insufficient to educate students regarding the cyberbullying phenomenon, which is why schools should have such ongoing programs throughout the entire school year.

Furthermore, such prevention and coping programs should be designed not only for students but also for adults (teachers and parents alike) so as to enable them to identify cyberbullying, to cope with it and to protect children from its harmful effects.

This study has been beneficial not only for the students in the focus group but also for us as educators, offering us a more comprehensive view of the phenomenon, prompting us to delve deeper into the topic, and helping us have open discussions with the students. Our students' interest in this topic, involvement in the experiment, and frank answers have been an invaluable tool.

We will strive to continue to raise awareness on this topic among students, colleagues, and parents and will suggest that cyberbullying prevention strategies be part of the school curriculum.

Authors note: The authors have equal contributions to this article.

Chiș Olga is a senior lecturer at the Department of Educational Sciences, Babeș-Bolyai University, ClujNapoca, Romania. She graduated with a Ph.D. in educational sciences and her fields of interest include: parental education, children's literacy, assessment of children in kindergarten and primary school.

Adina V. Lung is an English teacher holding a Masters of Education with an emphasis in school counseling. She is also a graduate of Babeș-Bolyai University in Cluj-Napoca, Romania.

\section{References}

Chiș, O. \& Grec, C. (2019). Effective ways to prevent bullying situations in Astra Salvensis, VII (2019), no. 14 , p. p. $39-48$. 
Dulamă, M.E., Ilovan, O.-R., Ciascai, L. \& Maroşi, Z. (2015). E-learning Geography. How powerful is Facebook for Geography university students? Proceedings of the $10^{\text {th }}$ International Conference on Virtual Learning, 121-127.

Dulamă, M.E., Ilovan, O.-R. \& Bus,, R.-M. (2016). Cultural landscapes and Geography university students' learning on Facebook discussion groups. Proceedings of the $11^{\text {th }}$ International Conference on Virtual Learning, 50-57.

Dulamă, M.E., Vana, V.M. \& Ilovan, O.-R. (2016). Assessing territorial planning M.Sc. students using Facebook. Proceedings of the $11^{\text {th }}$ International Conference on Virtual Learning, 66-74.

Hinduja, J. (2015). Bullying beyond the schoolyard: preventing and responding to cyberbullying. Corwin.

Dulamă, M.E., Ursu, C.-D., Ilovan, O.-R. \& Voicu, C.-G. (2019). Increasing generation $Z$ geography students' learning through didactic films in university. Proceedings of the $14^{\text {th }}$ International Conference on Virtual Learning, 79-85.

Ilovan, O.-R., Dulamă, M.E., Ciascai, L. \& Maroşi, Z. (2015). Geography university students' skills to research online sources. An empirical study. Proceedings of the $10^{\text {th }}$ International Conference on Virtual Learning, 201-134.
Ilovan, O.-R. (2019). Studying the urban landscape at university: web-based research and visual imagery. Proceedings of the $14^{\text {th }}$ International Conference on Virtual Learning, 70-78.

Ilovan, O.-R., Maroși, Z., Adorean, E.-C., Ursu, C.-D., Kobulniczky, B., Dulamă, M.E. \& Colcer, A.-M., (2019). E-Learning urban landscape changes in postsocialist Romania using digital mapping. Proceedings of the $14^{\text {th }}$ International Conference on Virtual Learning, $62-69$.

National Center for Missing and Exploited Children. (2019). Stuff to Know: What To Do If It Happens to You.Available at: www.nsteens.org (Accessed at 15.10.2020).

Rus, G.-M., Dulamă, M.E., Ursu, C.-D., Colcer, A.-M., Ilovan, O.-R., Jucu, I.S. \& Horvath, C. (2019). Online apps, web sources and electronic devices: learning through discovery about Valea Ierii [Iara Valley]. Proceedings of the $14^{\text {th }}$ International Conference on Virtual Learning, 110-119.

U.S. Department of Health and Human Services (2019). Facts about Bullying. Available at: https://www.stopbullying.gov/media/facts/index.html\#st ats (Accessed at 17.10.2020). 